Int. J. Morphol.,

30(2):394-398, 2012.

\title{
The Behavior of Demineralized Bone Matrix (DBM) in Post-Extraction Sockets
}

\author{
El Comportamiento de Matriz Ósea Desmineralizada (DBM) en Alvéolos Post-Extracción \\ "Ramón Fuentes; ** João Paulo Mardegan Issa; ***Mamie Mizusaki Iyomasa; \\ "Gonzalo Oporto; *** Ruth Prieto \& "Eduardo Borie
}

FUENTES, R.; ISSA, J.P.M.; IYOMASA, M.M.; OPORTO, G.; PRIETO, R.; BORIE, E. The behavior of demineralized bone matrix (DBM) in post-extraction sockets. Int. J. Morphol., 30(2):394-398, 2012.

SUMMARY: Autogenous bone grafts are considered to be the gold standard in bone regeneration because of their osteogenic activity; however, due to limited availability of intraoral donor sites and the need to resolve the demands of patients requires an alternative to these. Two male patients were submitted to implant surgery in two stages with 6 months intervals between each of them: the first was exodontia and placement of DBM graft into the socket; the second stage was the drill with a $2 \mathrm{~mm}$ internal diameter trephine in center of the alveolar ridge previously grafted with DBM and subsequent implant placement. The samples were analyzed under histological techniques. A very mature bone was observed at 6 months after DBM graft placement in the sockets, showing it to be a good alternative as bone graft.

KEY WORDS: Bone regeneration; Biomaterials; DBM; Socket.

\section{INTRODUCTION}

Osseointegrated implants are considered the ideal replacement for tooth loss; however, the success of an implant is related to the bone resorption in edentulous sites (Butterfield et al., 2004; Adeyemo et al., 2008). Alveolar resorption is a chronic, accumulative, irreversible and progressive disease, leading to esthetic and functional problems for implant installation (Wu et al., 2008). In addition, the rate of bone healing is slower than in other tissues; the use of biomaterials such as bone grafts that help the bone healing process is sometimes required (ChavesNetto et al., 2009).

On the other hand, some authors stated that autogenous bone grafts are considered to be the gold standard in bone regeneration because of their osteogenic activity (Giannoudis et al., 2005; Lee et al., 2008; Handschel et al., 2009). Acocella et al. (2010) exhibited that the fast healing of an autograft presents a unique advantage when compared with other biomaterials. However, the limited availability of intraoral donor sites, morbidity of the donor site and the need to resolve the demands of patients, requires the search for biomaterials that can be used to induce bone regeneration
(Olate et al., 2007; Adeyemo et al.; Wu et al.). Authors as Aghaloo et al. (2005) and Borie et al. (2011) mentioned that some allografts are good option to replace autografts.

DBM (demineralized bone matrix) is considered as a good osteoinductor in bone grafting biomaterials (Giannoudis et al., 2005; Zimmermann \& Moghaddam, 2011). DBM can be produced through decalcification of cortical bone in order to reduce the potential for infection and immunogenic host response. The DBM retains the trabecular collagenous structure of the original tissue and can act as a biologic osteoconductive scaffold despite the loss of structural strength once contributed by the preexisting bone mineral (Ludwig \& Boden, 1999). Bone demineralization does not eliminate all bone growth factors, which are now more bio-available with the mineral phase removed. Thus, DBM can be more osteoinductive than standard mineralized allograft (Sandhu et al., 1999; Fleming et al., 2000; Giannoudis et al., Zimmermann \& Moghaddam). Ozdemir \& Kir (2011) concluded in their research that DBM serves as a graft extender or enhancer for autogenous graft and decreases the need of autogenous bone graft in the

\footnotetext{
" Departmento de Odontología Integral, Universidad de la Frontera, Temuco, Chile.

${ }^{* *}$ Department of Morphology, Phisiology and Stomathology, Faculty of Dentistry of Ribeirão Preto, University of Sao Paulo, Ribeirão Preto, Brazil.

*** Departamento de Pediatría y Cirugía Infantil, Universidad de la Frontera, Temuco, Chile.
} 
treatment of bone defects because the union rate was better with the combination than with the use of any one of these grafts alone. Lim et al. (2011) stated that DBM promotes rapid bone ingrowth and gap healing around porous implants. Hatzokos et al. (2011) observed that application of demineralized bone matrix and autologous bone marrow is an effective treatment option, with minimal donor site morbidity, for reducing consolidation time of the docking site in tibial defects treated with distraction osteogenesis. The aim of this research was to assess histological the bone healing after six months in two patients in which Demineralized Bone Matrix (DBM) was applied in their post exodontia sockets.

\section{MATERIAL AND METHOD}

Patients and surgical procedures. Two male patients 45 and 55 years of age were treated by the Oral Implantology Division of the Universidad de La Frontera during 2010. The patients were informed about the research and were agreed to the procedure through and informed consent. Both patients required rehabilitation of pieces 3.4 and 3.5, respectively, with a unitary crown installed over osseous integrated implant. In both patients the teeth presented an extensive crown fracture with involvement of the root, which making further dental treatment impossible. Surgical sites presented inadequate alveolar ridge, absence of inflammatory processes and/or active infection. Bone reconstruction through the use of biomaterials and subsequent rehabilitation through assisted implant prosthesis unit (AIP) were indicated. With administration of local anesthesia (2\% lidocaine with epinephrine 1:200.000), the first surgery consisted in the extraction of two pieces with high rotation drills in order to segment the radicular remnant and realize the exodontia in accordance with conventional techniques; subsequently DBM was applied within the alveolar ridge (DynaGraft-D putty, Keystone Dental, Burlington, Massachusetts, U.S.A.) with alveolar curette. Suturing was realized with 3-0 silk threads, simple suture without the use of membrane or any other type of protective element. Six months later the second surgery was performed. Upon administration of local anesthesia (2\% lidocaine with epinephrine 1:100.000) mucoperiosteal flap was realized starting from lineal incision; bone material was obtained in the first stage by using a $2 \mathrm{~mm}$ internal diameter trephine, perforation was made in the center of the alveolar ridge previously grafted with DBM. The samples were submerged in buffered formalin at $10 \%$ and subsequently processed in the Comparative Embryology Laboratory of the Faculty of Medicine of the Universidad de Chile, through histological and histochemical techniques. In a second surgical stage the site prepared with trephine was extended with surgical drills achieving a site for implant of $11 \mathrm{~mm}$ in length and 3.75 $\mathrm{mm}$ in diameter (internal hexagon) with a primary stability of $45 \mathrm{Ncm}$.

Histological study. Samples of bone tissue were not decalcified and set to realize longitudinal $7 \mu \mathrm{m}$ cuts using microtome (Micron $\left.{ }^{\circledR}\right)$. Subsequently stained with Hematoxylin-eosin and Alcian blue (trichromic technique), Masson, Van Giesson, Von Kossa reaction and Picrosirius Junqueira method. Preparations analyzed using optic microscope (Zeiss $®$ ), with magnification of 20X, 50X and 100X, using Axiovision ${ }^{\circledR}$ computer software to identify bone and vascular structure and inflammatory infiltrate. The histological study was carried out in all images obtained.

\section{RESULTS}

None of the pacients had postoperative complications or infections.

The results of histological description showed:

- Mineralized bone trabeculae stained by Eosin-HematoxilinBlue Alcian showed lacunae within which the osteocyte lie. . Bone canaliculi were noted within lie the osteocyte filipodial processes (Fig. 1A).

- Bone trabeculae irregular in shape and size surround a loose connective tissue showing few zones with inflammatory cells as polymorphonuclears (PMNs) were observed (Fig. 1B).

- The peripheral tissue of the sample was completely mineralized and consolidated but in center was identified mineralized trabeculae with some Havers system and connective tissue (Fig. 1C).

- Using Picrosirius Junqueira method stain a lot of collagen fibrils were observed, that laid down in organized manner and form a thick collagen fibers in some region. (Fig. 1D).

- Several mineralized bone trabeculae with irregular size were observed in the connective tissue. In the newly formed bone trabeculae the lacunae were identified, where the osteocyte lied. (Fig. 2A).

- In the connective tissue were identified the mineralized mature bone matrix with irregular shape showing the lacunae (Fig. 2B).

- No remaining intact biomaterial was observed in any of the biopsies. 


\section{DISCUSSION}

DBM is considered as a good osteoinductor in bone grafting biomaterials (Giannoudis et al.; Zimmermann \& Moghaddam). Osteoinductivity occurs when the graft material has properties to induce pluripotent mesenchymal cells, derived from the recipient site or from the circulation, to differentiate into osteoblasts, stimulating bone neogenesis (Porrini et al., 2011; Umulis et al., 2009).
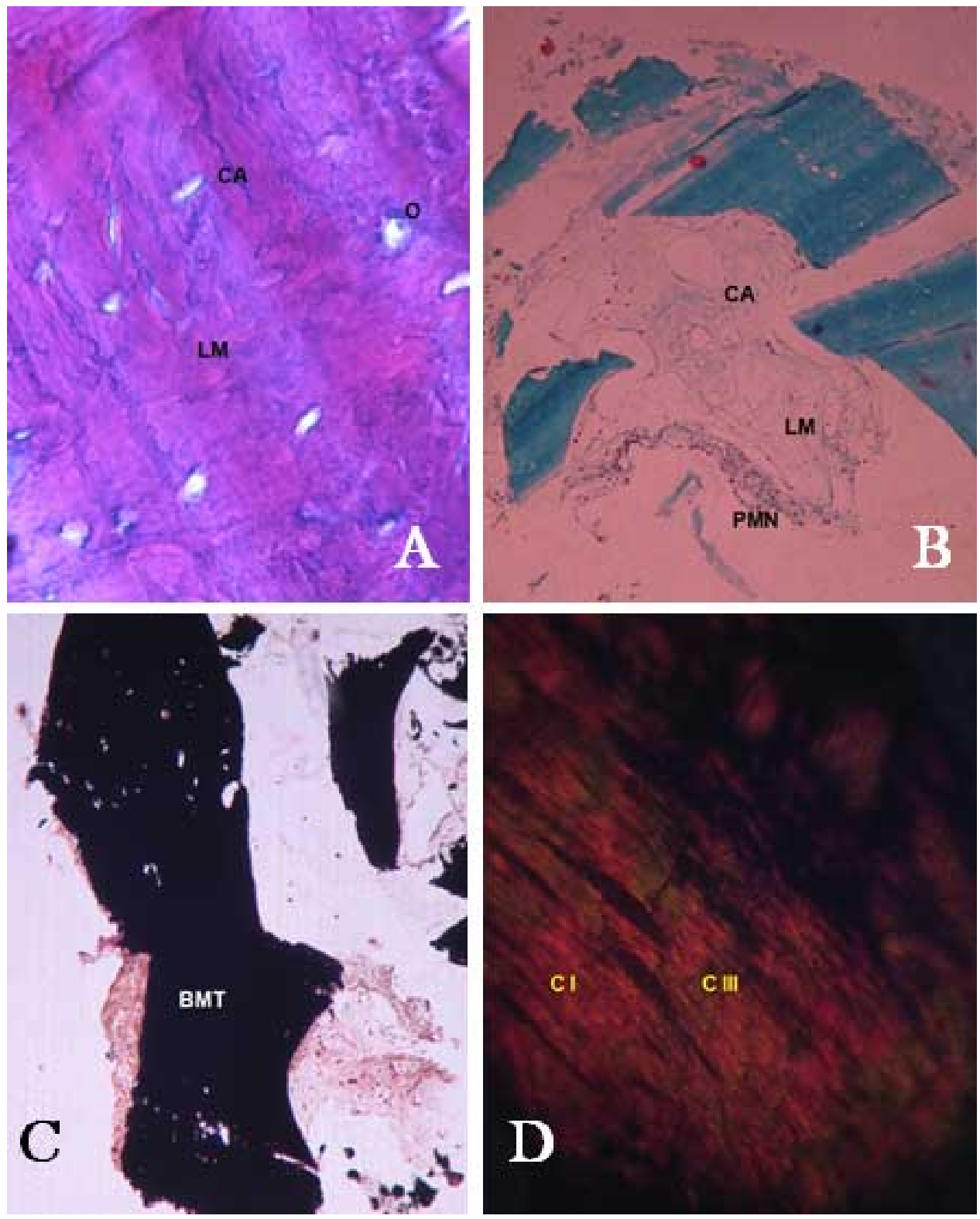

Fig. 1. A.- Bone Canaliculi (CA), Lax Matrix (LM) and Osteocytes (O), Eosin-Hematoxilin-Blue Alcian stain 100X.; B.- Bone Canaliculi (CA), Lax Matrix (LM) and Polymorphonuclears (PMN), Masson stain 50X.; C.- Bone mineralized tissue (BMT), Von Kossa reaction, 20X.; D.- Collagen type I fibers (CI) and Collagen type III fibers (CIII), Picrosirius Junqueira method, 100X.
Histological findings of no decalcified of bone samples showed a mineralized and mature bone matrix with several lacunae suggesting that 6 months period after DBM graft placement was suitable for bone regeneration and maturation of receptor site. This healing period of 6 months concurs with Lee et al. (2011), when they used a combination of autogenous bone grafts and platelet-enriched fibrin glue. On the other hand, in a sinus lift augmentation realized by Won et al. (2011) with DBM, they found new bone formation and osteoid tissue at 9 months after graft placement, which indicates that at this time immature bone were formed.

In the mineralized bone, an abundance of collagenous fibers was one of the great achievement observed in the samples, that is one of determinants of bone strength. In addition, lacunae and canaliculi in the bone trabeculae were found within which lie respectively, the osteocyte cell and its filipodial processes, which is indicator of the maintenance of bone tissue, since the function of the osteocyte is mechanosensation, which is important to transduce stress signals from bending or stretching of bone into biologic atividade.

The mineralized bone tissue found in our samples confirm that DBM possesses the properties of o s t e o ind u t i v i t y (Zimmermann \& Moghaddam, 2011) and osteocondutivity (Ludwig \& Boden, 1999). Its suggested that DBM acts as a better bone graft than Freeze Dried Bone Allogaft, compared with the results for the FDBA by Fuentes et al. (2011), when only collagen fibers type I were found in the sample.

Some studies on maxillary sinus lift using 
DBM have demonstrated remineralization and new bone formation leading to increased levels of inorganic substances, which allows implant placement (Schwartz et al., 2007; Won et al.). The above concurs with the cases here presented because the implant were placed, osseointegrated and rehabilitated without any problems.

It is now recognized that various configurations of DBM can differ with regard to the bone inductive activity, whose variability is assigned to the biologic properties of the graft and the preparation methods of allograft (while McMillan et al. (2007) stated that host physiology could also affect the osteoinduction response to DBM. However, these results showed that DBM might be a good option to replace autologous bone when it has a limited availability of donor sites concurring with Hatzokos et al. and Honsawek et al. (2011).

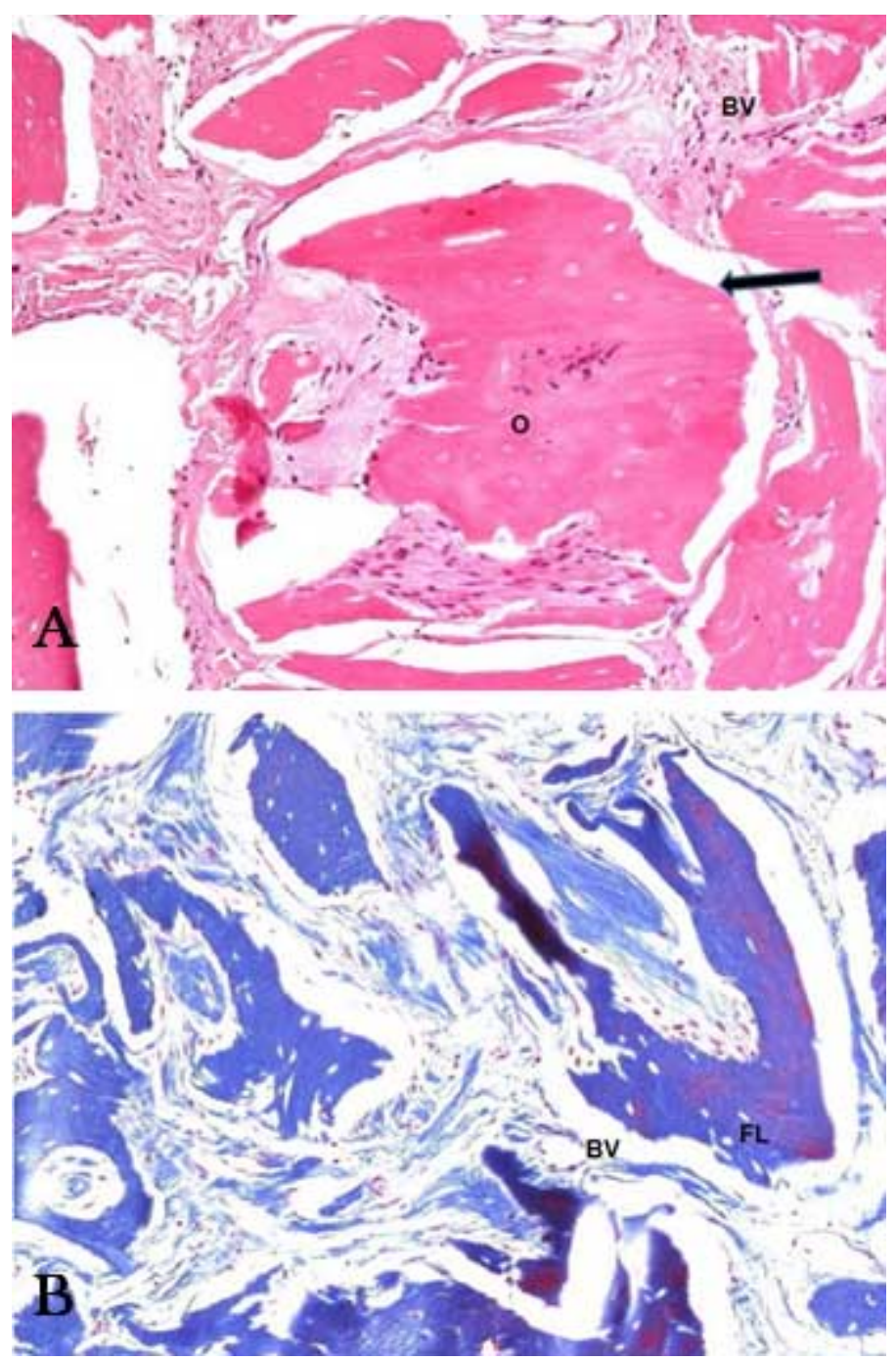

Fig. 2. A. Lacunae are seen sparingly $(\mathrm{O})$ with a few small-caliber blood vessels (BV). Note the peripheral zone without active fibroblasts or developed osteoblasts (arrow), Eosin-Hematoxilin stain 50X.; B.Note the few blood vessels (BV) and flat lacunae (FL), Van Giesson stain 50X.
In conclusion, this research showed the osteoinductive property of DBM in an early stage of 6 months after graft placement in the patients, noting bone tissue almost totally calcified showing that it could be an alternative of bone graft. In view of these results, it is necessary to continue the researches associated to the relation between biomaterial and boneresponse in humans.

FUENTES, R.; ISSA, J.P.M.; IYOMASA, M.M.; OPORTO, G.; PRIETO, R.; BORIE, E. El comportamiento de la matriz ósea desmineralizada (DBM) en alveolos postextracción. Int. J. Morphol., 30(2):394-398, 2012.

RESUMEN: Los injertos de hueso autólogo son considerados el "gold standard" en regeneración ósea debido a sus propiedades osteogénicas; sin embargo, debido a la limitada cantidad de sitios intraorales y la necesidad de resolver las necesidades de los pacientes, es que se requiere una alternativa para el mismo. Dos pacientes masculinos fueron sometidos a una cirugía de implantes en dos etapas con 6 meses de intervalo entre cada una de ellas: la primera consistió en la exodoncia y el posicionamiento del injerto de DBM en el alvéolo; la segunda etapa consistió en el fresado con una trefina de dos milímetros de diámetro interno en el centro del reborde alveolar previamente injertado con DBM y luego se posicionó el implante. Las muestras fueron analizadas bajo técnicas histológicas. Un hueso muy maduro fue observado a los 6 meses de haber injertado el DBM en los alvéolos, demostrando que podría ser una buena alternativa como injerto óseo.

PALABRAS CLAVE: Regeneración ósea; Biomateriales; DBM; Alvéolo.

\section{REFERENCES}

Acocella, A.; Bertolai, R.; Nissan, J. \& Sacco, R. Clinical, histological and histomorphometrical study of maxillary sinus augmentation using cortico-cancellous fresh frozen bone chips. J. Craniomaxillofac. Surg., 39(3):192-9, 2011.

Adeyemo, W. L.; Reuther, T.; Bloch, W.; Korkmaz, Y.; Fischer, J. H.; Zöller, J. E. \& Kuebler, A. C. Healing of onlay mandibular bone grafts covered with collagen membrane or bovine bone substitutes: A microscopical and immunohistochemical study in the sheep. Int. J. Oral Maxillofac. Surg., 37(7):651-9, 2008.

Aghaloo, T. L.; Moy, P. K.; Ferymiller, E. G. Evaluation of platelet-rich plasma in combination with freeze-dried bone in the rabbit calvarium: A pilot study. Clin. Oral Impl. Res., 16(2):250-7, 2005. 
Borie, E.; Fuentes, R.; del Sol, M.; Oporto, G. \& Engelke, W. The influence of FDBA and autogenous bone particles on regeneration of calvaria defects in the rabbit: A pilot study. Ann. Anat., 193(5):412-7, 2011.

Butterfield, K.; Bennett, J.; Gronowicz, G. \& Adams, D. Effect of PRP with autogenous bone graft for maxillary sinus augmentation in a rabbit model. J. Oral Maxillofac. Surg., 63(3):370-6, 2004.

Chaves Netto, H. D.; Olate, S.; Chaves, M. G.; Barbosa, J. R. \& Mazzonetto, R. Análisis Histológico del Proceso de Reparación en Defectos Óseos: Reconocimiento de Defectos Críticos. Int. J. Morphol., 27(4):1121-7, 2009.

Fleming, Jr. J. E.; Cornell, C. N. \& Muschler, G. F. Bone cells and matrices in orthopedic tissue engineering. Orthop. Clin. North Am., 31:357-74, 2000.

Fuentes, R.; Oporto, G.; Olate, S.; Rojas, M.; Borie, E. \& Engelke, W. Histological evaluation of bone regeneration means freeze dried bone allograft (FDBA) in post exodontia sockets. Int. J. Morphol., 29(1):286-92, 2011.

Giannoudis, P. V.; Dinopoulos, H. \& Tsiridis, E. Bone substitutes: An update. Injury, 36(S3): S20-7, 2005.

Handschel, J.; Simonowska, M.; Naujoks, C.; Depprich, R. A.; Ommerborn, M. A.; Meyer, U. \& Kübler, N. R. A histomorphometric meta-analysis of sinus elevation with various grafting materials. Head Face Med., 5:12, 2009.

Hatzokos, I.; Stavridis, S. I.; Iosifidou, E.; Karataglis, D. \& Christodoulou, A. Autologous bone marrow grafting combined with demineralized bone matrix improves consolidation of docking site after distraction osteogenesis. J. Bone Joint Surg., 93(7):671-8, 2011

Honsawek, S.; Bumrungpanichthaworn, P.; Thitiset, T. \& Wolfinbarger, Jr. L. Gene expression analysis of demineralized bone matrix-induced osteogenesis in human periosteal cells using cDNA array technology. Genet. Mol. Res., 10(3): 2093103, 2011.

Lee, C. Y. S., Prasad, H. S., Suzuki, J. B., Stover, J. D., Rohrer, M. D. The Correlation of Bone Mineral Density and Histologic Data in the Early Grafted Maxillary Sinus: A Preliminary Report. Implant. Dent., 20(3):202-14, 2011.

Lee, H. J.; Choi, B. H.; Jung, J. H.; Zhu, S. J.; Lee, S. H.; Huh, J. Y.; You, T. M. \& Li, J. Vertical alveolar ridge augmentation using autogenous bone grafts and platelet-enriched fibrin glue with simultaneous implant placement. Oral Surg. Oral Med. Oral Pathol. Oral Radiol. Endod., 105(1):27-31, 2008.

Lim, L.; Bobyn, J. D.; Bobyn, K. M.; Lefebvre, L. P.; Tanzer, M. The Otto Aufranc Award: Demineralized Bone Matrix Around Porous Implants Promotes Rapid Gap Healing and Bone Ingrowth. Clin. Orthop. Relat. Res. 2011. DOI 10.1007/s11999-011-2011-y
Ludwig, S. C. \& Boden, S. D. Osteoinductive bone graft substitutes for spinal fusion: a basic science summary. Orthop. Clin. North Am., 30(4):635-45, 199.

McMillan, J.; Kinney, R.C.; Ranly, D. M.; Fatehi-Sedeh, S.; Schwartz, Z. \& Boyan, B. D. Osteoinductivity of demineralized bone matrix in immunocompromised mice and rats is decreased by ovariectomy and restored by estrogen replacement. Bone, 40(1):111-21, 2007.

Olate, S.; de Oliveira, G.R.; Jaimes, M. \& Barbosa, J. R. A. Reparación ósea en procedimientos de reconstrucción y colocación de implantes. Int. J. Morphol., 25(3): 649-657, 2007.

Ozdemir, M. T. \& Kit, M. Ç. Repair of long bone defects with demineralized bone matrix and autogenous bone composite. Indian J. Orthop., 45(3):226-30, 2011.

Porrini, R.; Rocchetti, V.; Vercellino, V.; Cannas, M. \& Sabbatini, M. Alveolar regeneration in post-extraction socket: A review of materials to postpone dental implant. Biomed. Mater. Eng., 21(2):63-74, 2011.

Sandhu, H. S.; Grewal, H. S. \& Parvataneni, H. Bone grafting for spinal fusion. Orthop. Clin. North Am., 30(4):685-98, 1999.

Schwartz, Z.; Godlstein, M.; Raviv, E.; Hirsch, A.; Ranly, D. M. \& Boyan B. D. Clinical evaluation of demineralized bone allograft in a hyaluronic acid carrier for sinus lift augmentation in humans: a computed tomography and histomorphometric study. Clin. Oral Impl. Res., 18(2):204-11, 2007.

Umulis, D.; O’Connor, M. B.\& Blair, S. S. The extracellular regulation of bone morphogenetic protein signalling. Development, 136(22):3715-28, 2009.

Won, Y. H.; Kim, S. G.; Oh, J. S. \& Lim, S. C. Clinical Evaluation of Demineralized Bone Allograft for Sinus Lift in Humans: A Clinical and Histologic Study. Implant Dent., 20(6):460-4, 2011.

Wu, Z.; Liu, C.; Zang, G. \& Sun, H. The effect of simvastatin on remodelling of the alveolar bone following tooth extraction. Int . J. Oral Maxillofac. Surg., 37(2):170-6, 2008.

Zimmermann, G. \& Moghaddam, A. Allograft bone matrix versus synthetic bone graft substitutes. Injury, 42(S2): S16-21, 2011.

\section{Correspondence to:}

Ramón Fuentes Fernández

Departmento Odontología Integral

Facultad de Medicina

Universidad de la Frontera

Manuel Montt 112

Temuco-CHILE

Email: rfuentes@ufro.cl 